9. Лунеев В. В. Преступность XX века. Мировые, региональные и российские тенденции: мировой криминологический анализ. Ин-т гос-ва и права РАН. Москва. Норма, 1999. 516 c.; Luneev V. V. Prestupnost XX veka. Mirovye, regionalnye i rossiyskie tendentsii: mirovoy kriminologicheskiy analiz. In-t gos-va i prava RAN. Moskva. Norma, 1999. $516 \mathrm{~s}$.

10. Ляхов Е. Г. Проблемы сотрудничества государств в борьбе с международным терроризмом. Москва: Междунар. отношения, 1979. 168 с.; Lyakhov Ye. G. Problemy sotrudnichestva gosudarstv v borbe s mezhdunarodnym terrorizmom. Moskva: Mezhdunar. otnosheniya, 1979. $168 \mathrm{~s}$.

11. Международная борьба с терроризмом (правовые аспекты): научноаналитический обзор. Москва: ИНИОН, 1988. 42 с.; Mezhdunarodnaya borba s terrorizmom (pravovye aspekty): nauchno-analiticheskiy obzor. Moskva: INION, 1988. 42s.

12. Конституція України від 28 червня 1996 p. URL: http://www.kmu.gov.ua/document/ 110977042/Constitution_eng.doc; Konstytutsiia Ukrainy vid 28 chervnia 1996 r. URL: http://www.kmu.gov.ua/document/ 110977042/Constitution_eng.doc.

\title{
D.M. Shebanic \\ THE CONSTITUTIONAL PRINCIPLES OF COUNTERACTION TO TERRORISM: COMPARATIVE LEGAL ANALYSIS
}

The article is devoted to the comparative legal study of the constitutional foundations of counteracting terrorism in Ukraine and foreign states at the present stage and in historical retrospect.

Key words: terrorism, historical background, constitutional law, counteraction to terrorism, national antiterrorist system.

Стаття надійшла до редакції 24.10.2019 р.

УДК 354.07:351.176: [07:316.658](477)

\section{П. О. Яковлєв}

\section{КОМПЕТЕНЦІЯ ВИЩИХ ОРГАНІВ ДЕРЖАВНОЇ ВЛАДИ УКРАЇНИ У СФЕРІ ЗАБЕЗПЕЧЕННЯ ІНФОРМАЦИЙНОЇ БЕЗПЕКИ}

Стаття присвячена висвітленню особливостей компетениії вищих органів державного управління України у сфері забезпечення інформаційної безпеки держави. Зазначено, щуо основні ризики і загрози інформачійній безпечі Украйни детермінуються значними темпами розвитку інформатизації $і$ інформаційної структури суспільства. Обгрунтовано, що забезпечення інформаційної безпеки держави $є$ пріорітетним завданням діяльності всієї системи органів державного управління України $i$ передбачає визначення інновачійних підходів до формування системи захисту та розвитку інформаційного простору в умовах глобалізації та вільного обігу інформації.

Запропоновано авторське визначення категорії "компетенція вищих органів державної влади Украӥни у сфері забезпечення інформаційної безпеки», зміст якої передбачає систему визначених у нормативно-правових акта владних повноважень, які застосовуються з метою виявлення $i$ попередження загроз інформаційному суверенітету Украӥни, захисту національного інформаційного простору від здійснення 
спеціальних інформаційних операцій, спрямованих на підрив обороноздатності, деморалізацію особового складу Збройних Сил Украйни та інших військових формувань, провокування екстремістських проявів, підживлення панічних настроїв, загострення $i$ дестабілізачію суспільно-політичної та сочіально-економічної ситуачї, розпалювання міжетнічних і міжконфесійних конфліктів в Україні.

На підставі системного аналізу законодавства, яке регулює правовий статус парламенту Украӥни, Президента Украӥни і Кабінету Міністрів Украӥни, визначено основні їх повноваження у сфері забезпечення інформаційної безпеки. Акцентовано увагу на значенні діяльності Ради національної безпеки і оборони України як інституиіі координації Президентом України державної політики у сфері захисту інформаційних інтересів українського суспільства.

Обгрунтовано, щзо нормативна регламентаџія компетенції у сфері інформаційної безпеки України характеризується несистемністю, а спеціальні повноваження у сфері захисту інформації потребують конкретизації і деталізації. Зокрема, запропоновано на законодавчому рівні унормувати повноваження Уряду України у сфері забезпечення інформаційної безпеки з урахуванням існуючих сьогодні актуальних загроз для національного інформачійного суверенітету Украӥни.

Ключові слова: Україна, вищі органи влади, компетенція, інформація, інформачійна безпека, інфоһмачійна диверсія, інформачійні відносини, Президент Украӥни, Верховна Рада Украӥни, Кабінет міністрів Украӥни.

DOI 10.34079/2226-3047-2019-9-18-75-82

Постановка проблеми у загальному вигляді та зв'язок із важливими науковими чи практичними завданнями. На початку XXI століття у розвинених державах сучасного світу інформація є одним із найбільш важливих ресурсів розвитку як соціально-економічної, так і політико-правової сфери. Більше того, рівень розвитку національної системи інформатизації визначає ефективність забезпечення національних інтересів, керованість економікою, ступінь розвитку наукоємних виробництв та високих технологій, темпи зростання продуктивності праці, вдосконалення соціальноекономічних відносин, збагачення духовного життя та подальшої демократизації суспільства [1, с. 4]. На тлі зростання можливостей позитивного впливу розвитку інформаційної інфраструктури суспільства на процеси державотворення, не можна не враховувати потенційно небезпечних ризиків і загроз, які несе у собі інорфмаційнотехнічний пргорес. Це виявляється у інформаційної зброї, яка стала засобом досягнення корпоративних політичних цілей і чинником ураження національних інтересів держав.

У Рішенні Ради національної безпеки і оборони України (далі - РНБО) від 29.12.2016 p. «Про Доктрину інформаційної безпеки України» (далі - Доктрина інформаційної безпеки) визначено, що проти України останнім часом застосовуються найновіші інформаційні технології впливу на свідомість громадян, спрямовані на розпалювання національної і релігійної ворожнечі, пропаганду агресивної війни, зміну конституційного ладу насильницьким шляхом або порушення суверенітету i територіальної цілісності України [2]. Відповідно, забезпечення інформаційної безпеки держави $є$ пріорітетним завданням діяльності всієї системи органів державного управління, що потребує визначення інноваційних підходів до формування системи захисту та розвитку інформаційного простору в умовах глобалізації та вільного обігу інформації. У зазначеному контексті завданням юридичної доктрини є обгрунтування організаційно-правових форм i методів забезпечення інформаційного суверенітету держави, захисту публічних інтересів від інформаційних диверсій і атак. У звязку з 
цим, метою статті $є$ висвітлення компетенції вищих органів державної влади у сфері забезпечення інформаційної безпеки України.

Аналіз останніх досліджень і публікацій, в яких започатковано розв'язання даної проблеми. Опрацювання результатів наукових напрацювань 3 питань забезпечення інформаційної безпеки України дає підстави зауважити, що аспекти, які стосуються компетенції вищих органів державної влади, висвітлені у наукових працях не достатньо і потребують поглибленої розробки. Науково-інформаційною основою статті стали наукові праці таких вчених як Ю. Битяк, Т. Карабін, С. Мельник, П. Рудик, К. Тарасенко та ін.

Виклад основного матеріалу. Ефективність і результативність виконання такого складного і життєво важливого для держави завдання, як забезпечення іiї інформаційної безпеки, залежить від багатьох політико-правових, управлінських, гуманітарних, соціально-культурних, економічних, геополітичних та інших чинників. Визначальним у зазначеному контексті $\epsilon$ злагоджене функціонування системи вищих органів державного управління, які здійснюють формування і реалізацію внутрішньої політики держави включаючи гарантування інформаційної безпеки у контексті забезпечення обороноздатності країни. Перш за все, мова йде про Президента України, Кабінет Міністрів України, Раду національної безпеки і оборони держави. Їх компетенція в інформаційній сфері розрахована безпосередньо на попередження й відвернення інформаційних диверсій, дезинформації населення та інших небезпечних викликів і загроз системі національної інформаційної інфраструктури. Аналіз законодавчо встановленої компетенції цих суб'єктів дозволить критично оцінити потенціал організаційно-правових можливостей держави гарантувати інформаційну безпеку України.

Компетенція державного органу розглядається вченими як система взаємопов'язаних правоможностей, якими наділяється той чи інший державний орган. Ю. Битяк тлумачить термін «компетенція» як коло питань, передбачених законами, іншими нормативно-правовими актами, які конкретний орган має право вирішувати у процесі своєї практичної діяльності [3, с. 59]. Вирішувати необхідні питання державний орган може шляхом реалізації своїх повноважень. Сучасна юридична доктрина розглядає компетенцію ширше, включаючи до неї й інші складники, зокрема, предмет відання і юридичну відповідальність [4, с. 225]. 3 урахуванням того, що у національній правовій системі не існує уніфікованих визначень багатьох категорій якими можна охарактеризувати загрози інформаційній безпеці («інформаційна атака», «інформаційна диверсія», «інформаційна зброя») визначення компетенції вищих органів державної влади в означеній сфері передбачає врахування негативного впливу таких явищ. Відповідно, компетенцією вищих органів державної влади України у сфері забезпечення інформачійної безпеки пропонуємо розуміти як систему передбачених нормативно-правовими актами владних повноважень, які застосовуються з метою виявлення $i$ попередження загроз інформаційному суверенітету України, захисту національного інформаційного простору від здійснення спеціальних інформачійних операцій, спрямованих на підрив обороноздатності, деморалізацію особового складу Збройних Сил України та інших військових формувань, провокування екстремістських проявів, підживлення панічних настроїв, загострення $i$ дестабілізацію суспільнополітичної та сочіально-економічної ситуачії, розпалювання міжетнічних $i$ міжконфесійних конфліктів в Украӥні.

Беручи до уваги те, що органи державної влади вищого щабля формують засади внутрішньої і зовнішньої державної політики, відзначимо, що загальним предметом відання в частині забезпечення інформаційної безпеки є інформаційний компонент 
національної безпеки як стан захищеності інформаційного суверенітету держави, інформаційного простору України, технічної інформаційної інфраструктури від реальних і потенційних загроз. Відповідно, спеціальний предмет відання в частині забезпечення інформаційної безпеки становить розробка і реалізація концептуальних засад протидії інформаційним можливим формам протиправного посягання на інформаційні відносини у державі (інформаційні диверсії, інформаційні атаки, цілеспрямована дезинформація населення, пропаганда ворожнечі через ЗМІ та ін.).

Компетенція суб'єктів державного управління вищого рівня, що формують державну політику у сфері національної безпеки й оброни, представлена законотворчою i владно-розпорядчою управлінською діяльністю Верховної Ради України, Президента України, його допоміжними структурами й Кабінету Міністрів України.

Національний парламент Верховна Рада України як вищий орган законодавчої влади не наділена спеціальними інституціоналізованими повноваженнями у секторі національної безпеки [5, с. 98]. Але, законотворча й контрольна функції парламенту є базовими передумовами для формування нормативних основ функціонування інших вищих органів державної влади у секторі забезпечення інформаційної безпеки України. Крмі цього, Верховна Рада приймає закони з питань інформаційних відносин та їх забезпечення, здійснює парламентський контроль за виконанням законів України у сфері інформації, затверджує обсяг бюджетних асигнувань інших органів влади, які безпосередньо здійснюють управління у сфері формування інформаційного поля суспільства.

Згідно із п. 2.3 Стратегічного оборонного бюлетеня України значення Верховної Ради України в аспекті забезпечення національної безпеки є винятково важливою [6]. Саме Верховна Рада України має повноваження затверджувати загальну структуру й чисельність спеціальних інституцій, що протидіють інформаційній агресії проти України (підрозділи Збройних Сил України, Служба безпеки України, спеціальні підрозділи Міністерства внутрішніх справ тощо). Верховна Рада, у порядку виконання контрольної функції, уповноважена створювати тимчасові спеціальні (або слідчі) комісії, які можуть функціонувати з метою зясування проблематики діяльності Уряду, Служби безпеки України, інших мілітарних структур у напрямі забезпечення інформаційної безпеки. Крім цього, у іiі структурі функціонує Комітет 3 питань гуманітарної та інформаційної політики, який планує законодавче забезпечення державної політики у сфері інформації та інформаційної безпеки (крім питань, що належать до сфери національної безпеки та оборони) [7].

Порівняно з парламентом, Президент України наділений максимально широким переліком правотворчих, управлінських, розпорядчих і контрольних повноважень у сфері забезпечення інформаційної безпеки держави. Це випливає з його повноважень у сфері національної безпеки. Згідно зі ст. 13 Закону «Про національну безпеку України» стратегічне політичне керівництво у сфері національної безпеки й оборони держави здійснює Глава держави [8]. Для виконання цього завдання Президент України здійснює такі повноваження: вводить у дію дію рішення Ради національної безпеки і оборони з питань інформаційної безпеки, видає укази і розпорядження з питань інофрмаційної безпеки, затверджує Стратегію національної безпеки України, Стратегію воєнної безпеки України, інші програмні документи в означеній сфері, ініціює заходи державної політики в сфері забезпечення інформаційного суверенітету України, виступає із законодавчими ініціативами 3 питань законодавчого врегулювання інформаційної безпеки, здійснює кадрові повноваження щодо формування керівного складу спеціальних органів, що забезпечують інформаційну безпеку тощо. 
3 огляду на доволі значний перелік повноважень Президента України у сфері забезпечення національної безпеки й оборони вважаємо доцільним зазначити, що ефективність їх виконання багато в чому залежить від ефективності виконання Главою держави також інших управлінських функцій. Як слушно зауважує П. Рудик, гарантування національної безпеки в Україні є можливим лише шляхом проведення комплексної державної політики в економічній, соціальній, політичній, військовій, екологічній, науково-технічній та інформаційній сферах суб'єктами державного управління, причому об'єднаними зусиллями не лише Глави держави, а й громадських організацій і їх посадових осіб [9, с. 12]. Слід зазначити, що Президент як Глава Ради національної безпеки і оборони України також здійснює упралінський вплив на інформаційну безпеку посередництвом введення у дію рішень Ради національної безпеки і оборони держави (далі - РНБО). Рішення РНБО мають імперативний характер та першочергове значення для органів забезпечення національної безпеки i обороноздатності держави.

Посередництвом РНБО здійснюється координаційна діяльність Глави держави у сфері управління інформаційною безпекою України. Координаційна діяльність РНБО, як слушно відзначає К. Тарасенко, координаційна діяльність РНБО полягає в забезпеченні узгодженості в роботі різних органів державної влади та їх структурних підрозділів, а також органів місцевого самоврядування шляхом установлення системних і стабільних зв'язків між ними, зокрема, у сфері національної безпеки і оборони [10, с. 681]. РНБО також наділена повноваженнями у сфері стратегічного планування забезпечення реалізації державної політики у сферах національної i, зокрема, інформаційної безпеки шляхом розроблення стратегій, концепцій, програм, планів розвитку органів сектору безпеки й оборони, управління ресурсами захисту національної інформаційної інфраструктури України. Крім цього, РНБО здійснює забезпечення надходження необхідної інформації про загрози національній безпеці, їі опрацювання і збереження, конфіденційності й використання в інтересах України, контроль за цими діями, аналіз на основі інформації стану й тенденції розвитку подій, що відбуваються в Україні й у світі, визначення потенційних і реальних загроз національним інтересам України, залучає до аналізу інформації посадових осіб i фахівців органів виконавчої влади, державних установ, наукових закладів, підприємств та організацій усіх форм власності.

Кабінет Міністрів України у сфері інформаційної безпеки також уповноважений здійснювати певні заходи. У відповідності з Доктриною інформаційної безпеки України, Кабінет Міністрів забезпечує здійснення інформаційної політики держави, фінансування програм, пов'язаних 3 інформаційною безпекою, спрямування i координація роботи міністерств, інших органів виконавчої влади у цій сфері, здійснення розвитку урядових комунікацій. Слід зазначити, що незважаючи на те, що сьогодні в більшості держав світу спостерігається тенденція до посилення політичних позицій уряду, національна модель урядової компетенції в частині забезпечення інформаційної безпеки порівняно з повноваженнями Президента України є незначною. Саме тому ми $є$ прибічниками розширення кола повноважень уряду щодо забезпечення інформаційної безпеки держави. Зокрема, пропонуємо наділити Кабінет Міністрів правом розробляти і вводити в дію цільові програми забезпечення інформаційної безпеки всієї системи органів виконавчої влади, визначати ступінь обов'язковозті і форми залучення місцевих органів виконавчої влади до формування інформаційного середовища в регіонах, ровзивати систему інтернет-комунікацій між органами виконавчої влади всіх рівнів. 
Висновки і перспективи подальших наукових досліджень. На теперішній час вищі органи державної влади наділені значним обсягом повноважень у сфері забезпечення інформаційної безпеки України. Разом із тим, нормативна регламентація компетенції у сфері інформаційної безпеки характеризується несистемністю, а спеціальні повноваження потребують конкретизації і більш детального визначення. Ососбливо дається взнаки недостатній рівень нормативного визначення повноважень у сфері забезпечення інформаційної безпеки Кабінету Міністрів України. Вважаємо, що на законодавчому рівні повноваження Уряду України у сфері забезпечення інформаційної безпеки слід чітко систематизувати з урахуванням існуючих сьогодні актуальних загроз для національного інформаційного суверенітету. Відповідно, пріортетним напрямом подальших наукових досліджень у цьому напрямі має стати обгрунтування найбільш оптимальних форм адміністрування забезпечення інформаційної безпеки України вищими органами державної влади.

\section{Список використаної літератури}

1. Пожуєв В. І. Осмислення місця і ролі інформації в сучасному суспільстві. Гуманітарний вісник ЗДІА. 2010. № 42. C. 4 - 13; Pozhuyev V. I. Osmyslennya miscya i roli informaciyi v suchasnomu suspilstvi. Gumanitarnyj visnyk ZDIA. 2010. № 42. S. 4 - 13.

2. Про рішення Ради національної безпеки і оборони України від 29 грудня 2016 року «Про Доктрину інформаційної безпеки України» : Указ Президента України від 25 лютого 2017 року № 47/217. Офіиійний вісник Президента Украӥни. 2017. № 5. стор. 15; Pro rishennya Rady nacional’noyi bezpeky i oborony Ukrayiny vid 29 grudnya 2016 roku «Pro Doktry`nu informacijnoyi bezpeky Ukrayiny» : Ukaz Prezydenta Ukrayiny vid 25 lyutogo 2017 roku № 47/217. Oficijnyj visnyk Prezydenta Ukrayiny. 2017. № 5. stor. 15.

3. Битяк Ю. П., Богуцький В. В., Гаращук В. М. Адміністративне право України: підруч. Харків, 2000. 520 с.; Bytyak Yu. P., Boguczkyj V. V., Garashhuk V. M. Administraty`vne pravo Ukrayiny`: pidruch. Xarkiv, 2000. $520 \mathrm{~s}$.

4. Карабін Т. О. Компетенція місцевих органів державної виконавчої влади та органів місцевого самоврядування: теоретико-термінологічні аспекти. Держава і право. Юридичні $i$ політичні науки. 2005. № 29.2 С. 225; Karabin T. O. Kompetenciya miscevyx organiv derzhavnoyi vykonavchoyi vlady ta organiv miscevogo samovryaduvannya: teoretyko-terminologichni aspekty. Derzhava i pravo. Yury`dy`chni i polity`chni nauky. 2005. № 29. S. 225.

5. Мельник С. М. Адміністративно-правове регулювання повноважень Верховної Ради України у сфері військового управління. Приватне та публічне право. 2019. С. 97 100; Melnyk S. M. Administratyvno-pravove regulyuvannya povnovazhen Verxovnoyi Rady Ukrayiny u sferi vijskovogo upravlinnya. Pryvatne ta publichne pravo. 2019. S. 97-100.

6. Про рішення Ради національної безпеки і оборони України від 20 травня 2016 року «Про Стратегічний оборонний бюлетень України»: Указ Президента України від 06.06.2016 p. № 240/216. Офіиійний сайт Президента Украӥни. URL: https://www.president.gov.ua/documents/2402016-20137/ (дата звернення: 18.07.2018); Pro rishennya Rady nacionalnoyi bezpeky i oborony Ukrayiny vid 20 travnya 2016 roku «Pro Strategichny`j oboronny`j byuleten Ukrayiny»: Ukaz Prezy`denta Ukrayiny` vid 06.06.2016 r. № 240/216. Oficijnyj sajt Prezydenta Ukrayiny. URL: https://www.president.gov.ua/documents/2402016-20137/ (data zvernennya: 18.07.2018).

7. Предмети відання Комітету Верховної Ради України з питань гуманітарної та інформаційної політики. Офіційний інтернет-сайт Комітету Верховної Ради Украӥни 3 питань гуманітарної та інформачійної політики. URL: http://kompkd.rada.gov.ua/uploads/documents/32652.pdf $\quad$ (дата звернення: 18.11.2019); 
Predmety vidannya Komitetu Verxovnoyi Rady Ukrayiny z py`tan`gumanitarnoyi ta informacijnoyi polityky. Oficijnyj internet-sajt Komitetu Verxovnoyi Rady Ukrayiny z py`tan ` gumanitarnoyi ta informacijnoyi polity`ky`. URL: http://kompkd.rada.gov.ua/uploads/documents/32652.pdf (data zvernennya: 18.11.2019).

8. Про національну безпеку України: Закон від 21.06.2018 р. № 2469-VIII. Відомості Верховної Ради України. 2018. № 31. Ст. 241; Pro nacionalnu bezpeku Ukrayiny: Zakon vid 21.06.2018 r. № 2469-VIII. Vidomosti Verxovnoyi Rady Ukrayiny. 2018. № 31. St. 241.

9. Рудик П. Конституційно-правовий статус Президента України в умовах парламентсько-президентської республіки. Віче. 2014. № 20. С. 11-19; Rudy k P. Konstytucijno-pravovyj status Prezydenta Ukrayiny v umovax parlamentsko-prezydentskoyi respubliky. Viche. 2014. № 20. S. 11-19.

10. Тарасенко К. В. Компетенція, форми і методи діяльності та відповідальність Ради національної безпеки і оборони України. Форум права. 2012. № 2. С. 681; Tarasenko K. V. Kompetenciya, formy i metody diyalnosti ta vidpovida nist Rady nacionalnoyi bezpeky i oborony Ukrayiny. Forum prava. 2012. № 2. S. 681.

\section{P.Yakovlev}

\section{A COMPETENCE OF SUPREME BODIES OF STATE POWER OF UKRAINE IS IN THE FIELD OF PROVIDING OF INFORMATIVE SAFETY}

The article is sanctified to illumination of features of competence of supreme bodies of state administration of Ukraine in the field of providing of informative safety of the state. It is marked that basic risks and threat to informative safety of Ukraine determined by the considerable rates of development of normalization and informative structure of society. Reasonably, that providing of informative safety of the state is foreground job to activity of all system of organs of state administration of Ukraine and envisages determination of innovative approaches to forming of the system of defense and development of informative space in the conditions of globalization and free turnover of information.

Authorial determination of category offers "competence of supreme bodies of state power of Ukraine in the field of providing of informative safety", maintenance of that envisages the system of certain in normatively-legal act of imperious plenary powers, that are used with the aim of exposure and warning of threats to informative sovereignty of Ukraine, defense of national informative space from realization of the special informative operations, sent to injury of defensive capacity, demoralization of personnel of Armed force Ukraine and other soldiery forming, provocation extremist display, signup panicky mood, intensifying and destabilization social and political and socio-economic situation, kindling ethnic and inter confessional conflict in Ukraine.

On the basis of analysis of the systems of legislation, that regulates legal status of parliament of Ukraine, President of Ukraine and Cabinet of Ministers of Ukraine, their basic plenary powers are certain in the field of providing of informative safety. Attention is accented on the value of activity of national security and defensive of Ukraine Council as establishments of co-ordination of Ukraine of state politic President in the field of defense of informative interests of Ukrainian society.

Reasonably, that normative regulation of competence in the field of informative safety of Ukraine is characterized non system ness, and the special authorities in the field of defense of information need a specification and working out in detail. In particular, it offers at legislative level to ration plenary powers of Government of Ukraine in the field of providing 
of informative safety taking into account existent today actual threats for national informative sovereignty of Ukraine.

Key words: Ukraine, supreme bodies of power, competence, information, informative safety, informative diversion, informative relations, President of Ukraine, Supreme soviet of Ukraine, Cabinet of ministers of Ukraine.

Стаття надійшла до редакції 28.10.2019 р.

УДК: 343.352

\section{Н.Л.Шелухин}

\section{О ДОКТРИНАЛЬНОМ ТОЛКОВАНИИ ПОНЯТИЯ «КРИМИНОЛОГИЧЕСКАЯ ХАРАКТЕРИСТИКА»}

В статье анализируется понятие «криминологическая характеристика» с точки зрения отечественных и зарубежных исследователей.

Определение криминологической характеристики необходимо формулировать, учитывая межотраслевую природу криминологии и направления изучения состояния преступных проявлений. $K$ таким направлениям необходимо отнести: изучение преступности, изучение личности правонарушителя (преступника) и преступной среды, изучение жертвы преступления; изучение процесса ресоциализации правонарушителей.

Четко обозначены задачи криминологической характеристики - реализация системы мер по предупреждению/сдерживанию преступности и криминологическое прогнозирование.

Дано определение криминологической характеристики как локализованное в области права, социологии и социальной политики эклектическое, мультидисииплинарное комплексное описание социологических, психологических, медищинских, юридических, географических, сочииологических, политологических и других факторов, характеризующее: природу, причины и условия преступности как сочиального явления; личность правонарушителя (преступника) и преступной среды; сочииальный портрет жертвы преступления; процессы ресоциализации правонарушителей.

Ключевые слова: криминология, криминологическая характеристика, преступность, личность правонарушителя, преступная среда, жертва преступления, ресоичиализащчия.

DOI 10.34079/2226-3047-2019-9-18-82-93

После формирования криминологии как самостоятельной науки процесс становления категории криминологической характеристики был связан не только с систематизацией отдельных сведений о преступности, преступлениях, личности преступника, причинах и условиях преступности, не только с упорядочением уже известного в систему, а явился закономерным результатом развития понятийного аппарата науки, отражающего качественно новый подход в решении вопросов противодействия преступности. 